Przegląd Badań Edukacyjnych Educational Studies Review

ISSN 1895-4308

nr 19 (2/2014), s. 257-270

DONIESIENIA

Z PRAKTYKI

EDUKACYJNEJ

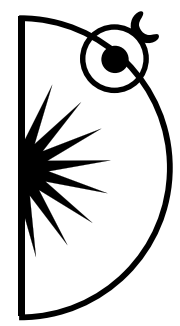

Anna Bieganowska

Uniwersytet Marii Curie-Skłodowskiej w Lublinie, e-mail: a.bieganowska@umcs.pl

Anna Witek

Uniwersytet Marii Curie-Skłodowskiej w Lublinie, e-mail: anna.witek@poczta.umcs.lublin.pl

\title{
Przygotowanie nauczycieli do pracy z uczniami ze specjalnymi potrzebami edukacyjnymi
}

DOI: http://dx.doi.org/10.12775/PBE.2014.032

\section{Training Teachers to Work with Special Educational Needs Students}

\begin{abstract}
This article analyses the issue of working with a special educational needs student. It discusses the objectives for academic tutors in terms of preparing students for work, according to educational standards of teacher training and the inclusion model premises. It presents the educational forms used at the academic level aimed at increasing the quality of didactic and tutorial work and effective organisation of psychological and pedagogical help for students with special educational needs.
\end{abstract}

Key words: inclusion, children with special educational needs, teacher training standards

\section{Wprowadzenie}

Szkoła powinna być miejscem optymalnego rozwoju dla wszystkich uczniów. Dlatego też, zgodnie ze stanowiskiem UNESCO z 1994 roku, postuluje się przyjmowanie do szkół wszystkich dzieci, ,niezależnie od ich warunków fizycznych, intelektualnych, socjalnych, emocjonalnych, językowych czy innych. 
Dotyczy to dzieci upośledzonych i utalentowanych, dzieci ulicy i dzieci pracujących, dzieci ze społeczności koczowniczych czy odległych, dzieci z mniejszości językowych, etnicznych czy kulturowych oraz dzieci z innych regionów lub grup nierównych szans, czy z marginesu społecznego" (European Agency for Development In Special Needs Education - EADSNE, 2009, s. 7-8). Grupy uczniów, którzy nie mogą podołać wymaganiom powszechnie obowiązującego programu edukacyjnego, określa się wspólnym terminem uczniów ze specjalnymi potrzebami edukacyjnymi.

Pojęcie ,specjalnych potrzeb edukacyjnych” wprowadzono po raz pierwszy w 1978 r., w Raporcie M. Warnock w Wielkiej Brytanii. Raport ten zwrócił uwagę na to, że „specjalne potrzeby edukacyjne dzieci i młodzieży wynikają ze zindywidualizowanego sposobu nabywania wiedzy i umiejętności w procesie uczenia się, określonego specyfiką ich funkcjonowania poznawczo-percepcyjnego" (Głodkowska, 2010, s. 41).

Zagadnienie pracy z uczniem ze specjalnymi potrzebami edukacyjnymi podejmowane jest $\mathrm{w}$ toku dyskusji nauczycieli akademickich przygotowujących studentów do pracy w zawodzie nauczyciela, samych nauczycieli pracujących w placówkach oświatowych oraz studentów. Dzieje się tak z uwagi na obserwowany współcześnie rozwój idei integracji i coraz częściej spotykany fakt edukacji dzieci ze specjalnymi potrzebami edukacyjnymi w szkołach z oddziałami integracyjnymi oraz w ogólnodostępnych. Oczekuje się, że kolejnym krokiem na drodze rozwoju edukacji uczniów ze specjalnymi potrzebami edukacyjnymi (SPE) będzie inkluzja. Będzie to oznaczało, ,że nie uczeń z trudnościami ma dostosować się do reguł szkoły ogólnodostępnej/integracyjnej, lecz to szkoła i środowisko ma usunąc bariery utrudniające funkcjonowanie zdrowotne, psychiczne i społeczne uczniowi ze szczególnymi potrzebami. W tym modelu [...] szkoła ma tak funkcjonować, aby być otwartą na wszystkich uczniów i gotową przyjąć każdego, kto chciałby w niej zdobywać wiedzę" (Domagała-Zyśk, 2012, s. 8). Stąd, przygotowując studentów w toku studiów do przyszłej pracy, należy przekazać wiedzę i umiejętności niezbędne do pracy dydaktycznej, przygotowania lekcji dostępnej dla każdego ucznia, a jednocześnie zadbania o klimat akceptacji dla dzieci ze specjalnymi potrzebami edukacyjnymi (Domagała-Zyśk, 2012, s. 8-9).

\section{Kształcenie studentów w zakresie pracy z uczniem ze specjalnymi potrzebami edukacyjnymi}

Kwestie dotyczące kształcenia przyszłych nauczycieli, pedagogów i psychologów w zakresie pracy z uczniem ze specjalnymi potrzebami edukacyj- 
nymi reguluje Rozporzqdzenie Ministra Nauki i Szkolnictwa Wyższego z dnia 17 stycznia 2012 r. w sprawie standardów kształcenia przygotowującego do wykonywania zawodu nauczyciela (Dz. U. z 2012 r., poz. 131). Obecnie obowiązujące Rozporzqdzenie (Dz. U. z 2012 r., poz. 131) w porównaniu z Rozporzqdzeniem Ministra Edukacji Narodowej i Sportu z dn. 7 września 2004 w sprawie standardów ksztatcenia nauczycieli (Dz. U. z 2004 r., poz. 2110) zdecydowanie więcej uwagi poświęca zagadnieniu diagnozowania, analizowania i prognozowania sytuacji pedagogicznych, związanych z pracą z uczniami ze specjalnymi potrzebami edukacyjnymi.

Obecnie w szczególny sposób akcentowane są kwestie konieczności prowadzenia zindywidualizowanych działań pedagogicznych w stosunku do omawianej grupy uczniów. Zmieniając standardy kształcenia nauczycieli założono, że każdy absolwent studiów wyższych zrealizowanych na podstawie przepisów ww. rozporządzenia będzie posiadał przynajmniej w stopniu podstawowym wiedzę pedagogiczną i psychologiczną z uwzględnieniem przygotowania do pracy z uczniami ze specjalnymi potrzebami edukacyjnymi (Dz. U. z 2012 r., poz. 131). Profesjonalnie prowadzone zajęcia dydaktyczne w formie ćwiczeń i wykładów w połączeniu z praktyką pedagogiczną zapoznają studenta ze spektrum zagadnień odnoszących się do pracy z dziećmi i młodzieżą, adekwatnie do wymagań stawianych przez dynamicznie zmieniającą się rzeczywistość. Mając na uwadze dążenie do podwyższania jakości kształcenia, założono, że przyszły nauczyciel powinien opanować umiejętności harmonizowania uczenia się każdego ucznia z osobna z uczeniem się całej klasy oraz uczenia się dziecka sprawnego z dzieckiem ze specjalnymi potrzebami edukacyjnymi. Edukacja i włączanie dzieci ze specjalnymi potrzebami edukacyjnymi w pracę klasy i całej społeczności szkolnej jest złożonym procesem pedagogicznym i społecznym, w którym kluczową rolę odgrywa dobrze przygotowany nauczyciel. Jego kompetencje metodyczne, diagnostyczne, terapeutyczne są kluczem do profesjonalnego postrzegania ucznia ze specjalnymi potrzebami wśród jego rówieśników (Skoczylas, 2012; Wyczesany, Gajdzica, 2006; O’Regan, 2005).

W myśl Rozporzqdzenia MEN w sprawie zasad udzielania i organizacji pomocy psychologiczno-pedagogicznej z dn. 30 kwietnia 2013 r. (Dz. U. z 2013 r., poz. 532) nauczyciel jest przygotowany do pracy z dziećmi ze specjalnymi potrzebami edukacyjnymi, gdy potrafi rozpoznać indywidualne potrzeby rozwojowe i edukacyjne ucznia oraz dokonać diagnozy indywidualnych możliwości psychofizycznych ucznia wynikających w szczególności:

1) z niepełnosprawności;

2) z niedostosowania społecznego; 
3) z zagrożenia niedostosowaniem społecznym;

4) ze szczególnych uzdolnień;

5) ze specyficznych trudności w uczeniu się;

6) z zaburzeń komunikacji językowej;

7) $z$ choroby przewlekłej;

8) z sytuacji kryzysowych lub traumatycznych;

9) z niepowodzeń edukacyjnych;

10) z zaniedbań środowiskowych związanych z sytuacją bytową ucznia i jego rodziny, sposobem spędzania czasu wolnego i kontaktami środowiskowymi;

11) z trudności adaptacyjnych związanych $\mathrm{z}$ różnicami kulturowymi lub ze zmianą środowiska edukacyjnego, w tym związanych z wcześniejszym kształceniem za granicą.

W szkole pomoc psychologiczno-pedagogiczna jest udzielana $\mathrm{w}$ trakcie bieżącej pracy $\mathrm{z}$ uczniem oraz $\mathrm{w}$ formie:

1) klas terapeutycznych;

2) zajęć rozwijających uzdolnienia;

3) zajęć dydaktyczno-wyrównawczych;

4) zajęć specjalistycznych: korekcyjno-kompensacyjnych, logopedycznych, socjoterapeutycznych oraz innych zajęć o charakterze terapeutycznym;

5) zajęć związanych z wyborem kierunku kształcenia i zawodu oraz planowaniem kształcenia i kariery zawodowej - w przypadku uczniów gimnazjum i szkół ponadgimnazjalnych;

6) warsztatów;

7) porad i konsultacji (Dz. U. z 2013 r., poz. 532).

Treści z zakresu pracy z uczniem ze specjalnymi potrzebami edukacyjnymi na poziomie kształcenia akademickiego przekazywane są studentom podczas realizacji zajęć ujętych w tzw. blok pedagogiczny i psychologiczny. Jednak z uwagi na szeroki zakres tematyczny bloków i ramy czasowe, atencja poświęcona pracy z uczniem ze specjalnymi potrzebami edukacyjnymi jest niewystarczająca. Z praktyczną realizacją dyrektyw zawartych w Rozporządzeniu (Dz. U. z 2013 r., poz. 532) student może zapoznać się w toku realizowanych praktyk pedagogicznych, metodycznych. Stwarzają one płaszczyznę do bezpośredniej obserwacji pracy nauczyciela, funkcjonowania klasy szkolnej jako grupy oraz poszczególnych uczniów, w tym objętych pomocą psychologiczno-pedagogiczną. Ponadto student pod okiem opiekuna praktyk realizuje wybrane czynności z zakresu działań dydaktyczno-wychowawczych. Łączenie teorii z praktyką 
pozwala na dokonanie wielu obserwacji i na ich podstawie wysnucie refleksji dotyczących $\mathrm{m}$.in. realizowania zasady indywidualizacji w pracy z uczniami ze specjalnymi potrzebami edukacyjnymi (Gajdzica, 2003).

Uczestnictwo w praktykach uzupełnia zakres wiedzy i umiejętności niezbędnych do wykonywania zawodu nauczyciela i pozwala studentowi na poznanie warsztatu pracy $\mathrm{w}$ zakresie radzenia sobie w codziennych sytuacjach dydaktyczno-wychowawczych. Dodatkowo w ramach zajęć warto wspólnie ze studentami przeanalizować rezultaty realizowanych w ostatnich latach projektów, przykładowo: 2010-2011 MEN w partnerstwie z Akademią Pedagogiki Specjalnej realizował projekt systemowy „Podniesienie efektywności kształcenia uczniów ze specjalnymi potrzebami edukacyjnymi”. W wyniku jego realizacji wyposażono szkoły w szereg materiałów dydaktycznych dla dyrektorów, nauczycieli i rodziców, mających na celu podniesienie jakości kształcenia i wychowania uczniów ze specjalnymi potrzebami edukacyjnymi (http://www.efs. men.gov.pl/attachments/article/877/ MEN_sprawozdanie_PO_KL_III_za_I_ procze_2010_r.pdf; www.brpd.gov.pl/wystapienia/ wyst2013_03_11.pdf).

Kolejny ciekawy projekt to „Raport dobrych praktyk edukacyjnych: Szkoła się opłaca", dotyczący wsparcia uczniów ze specjalnymi potrzebami edukacyjnymi (sfinansowany ze środków Priorytetu III Programu Operacyjnego Kapitał Ludzki, zrealizowany w Polsce w latach 2007-2013) służący doskonaleniu umiejętności w zakresie pracy z uczniami ze SPE [http://www.efs.men. gov.pl/attachments/article/899/ Ostateczna\%20wersja\%20Raportu.pdf].

Analizując zagadnienia związane z kształceniem uczniów ze specjalnymi potrzebami edukacyjnymi, warto wspomnieć, że obecnie w MEN trwają prace nad stworzeniem systemu wspomagania przedszkoli, szkół, placówek. Przygotowując rozwiązania w tym zakresie, kierowano się wynikami analiz przeprowadzanych m.in. w ramach projektu pn. „Wzmocnienie systemu wspierania rozwoju szkół ze szczególnym uwzględnieniem doskonalenia nauczycieli i doradztwa metodycznego" (projekt realizowany przez MEN w ramach POKL, Priorytet III Wysoka jakość oświaty, Poddziałanie 3.3.1. Efektywny system kształcenia i doskonalenia nauczycieli). W raporcie z realizacji tego projektu sformułowano rekomendacje dotyczące zmian w systemie doskonalenia nauczycieli, wskazując na konieczność powiązania systemu doskonalenia nauczycieli z systemem wspomagania szkół i placówek, tak aby kierowane do nauczycieli doskonalenie zawodowe pomogło im rozwiązywać problemy zaistniałe w danym środowisku szkolnym (www.brpd.gov.pl/wystapienia/wyst_2013_03_11.pdf). W nowej perspektywie finansowej na lata 2014-2020, planuje się realizację projektów, których celem będzie wsparcie szkół w zakresie indywidualizacji pracy z uczniem 
ze specjalnymi potrzebami edukacyjnymi. Placówka będzie mogła pozyskać specjalistyczny sprzęt, pomoc i środki dydaktyczne konieczne do rozpoznawania potrzeb, wspomagania rozwoju i prowadzenia terapii dzieci i młodzieży. Przygotowanie kadry pedagogicznej ma na celu usprawnienie efektywności pracy z dziećmi i młodzieżą ze specjalnymi potrzebami edukacyjnymi w zakresie organizowania i udzielania pomocy psychologiczno-pedagogicznej odpowiednio do rozpoznanych indywidualnych potrzeb rozwojowych i edukacyjnych dzieci i młodzieży (www.brpd.gov.pl/wystapienia/wyst_2013_03_11.pdf).

Uczelnia kształci zatem przyszłych nauczycieli, pedagogów w zakresie kwalifikacji potrzebnych do pracy w przedszkolach, szkołach i placówkach oświatowych. W tym celu opracowywane są plany studiów i sylabusy przedmiotów nauczania, uwzględniające wymogi prawne wynikające z cytowanych $\mathrm{w}$ artykule rozporządzeń. Istotne jest, by przepisy przygotowujące do zawodu nauczyciela były spójne z wymaganiami kwalifikacyjnymi. Dlatego, aby przyszły pedagog, nauczyciel, specjalista legitymował się kwalifikacjami do realizacji zadań edukacyjnych, standardy kształcenia na tych kierunkach powinny być spójne z przepisami prawa oświatowego (Serafin, 2012, s. 39).

Wszystkie wspomniane regulacje i podejmowane na ich podstawie działania są zbieżne z postulatami zawartymi w art. 24 Konwencji o Prawach Osób Niepełnosprawnych zatytułowanym Edukacja (Dz. U. z 2012 r., poz. 1169). W myśl tych zapisów każde z Państw-Stron uznaje prawo osób z niepełnosprawnością do edukacji na zasadach równych szans i bez dyskryminacji, w związku z tym zobowiązuje się do zapewnienia umożliwiającego integrację systemu kształcenia. Tylko taki system, jak podkreślają sygnatariusze dokumentu, pozwala osobom ze specjalnymi potrzebami edukacyjnymi na osiagnięcie pełnego rozwoju, poprzez wykorzystanie potencjału tkwiącego w każdej jednostce, rozwijanie mocnych stron, kompensowanie i korygowanie deficytów. Zwraca się uwagę na konieczność indywidualizowania oferowanego wsparcia w celu zmaksymalizowania rozwoju ucznia w każdej ze sfer. W tym najważniejszym dla osób z niepełnosprawnością dokumencie zwraca się uwagę nie tylko na zapewnienie wsparcia oraz szeregu ułatwień (od nauki alfabetu brajla czy języka migowego po inne alternatywne sposoby optymalizacji procesu kształcenia), ale dostrzega się w nim również szczególną rolę profesjonalnego przygotowania nauczyciela do pracy z uczniem ze specjalnymi potrzebami edukacyjnymi i konieczność ustawicznego kształcenia kadr pedagogicznych w tym zakresie. Mówi o tym pkt 4, art. 24 Konwencji:

„Aby wesprzeć realizację tego prawa [do edukacji], Państwa Strony podejmą odpowiednie środki w celu zatrudniania nauczycieli, w tym nauczycieli 
niepełnosprawnych, którzy mają kwalifikacje w zakresie używania języka migowego i/lub alfabetu Braille'a, oraz w celu szkolenia specjalistów i personelu pracujących na wszystkich szczeblach edukacji. Takie szkolenie będzie obejmować wiedzę na temat problemów niepełnosprawności i korzystanie ze wspomagających (augmentatywnych) i alternatywnych sposobów, środków i form komunikacji, technik i materiałów edukacyjnych, w celu wspierania osób niepełnosprawnych".

Jeżeli chodzi o przygotowanie nauczycieli do pracy z uczniami ze specjalnymi potrzebami, warto zwrócić uwagę na jeszcze jeden fakt. Efektywne kształcenie uczniów ze specjalnymi potrzebami edukacyjnymi to nie tylko merytoryczna wiedza i kompetencje dydaktyczne nauczyciela, ale również jego pozytywna postawa oraz efektywne działania w zakresie rozwijania pozytywnych postaw społecznych u pozostałych wychowanków.

Pozytywne nastawienie całego otoczenia, a zwłaszcza nauczycieli, ma duże znaczenie dla uczniów ze specjalnymi potrzebami edukacyjnymi - wpływa korzystnie nie tylko na wyniki nauczania, ale także na procesy rehabilitacji i integracji społecznej (por. Gałkowski, 2008, s. 21; Maciarz, 2001, s. 9). Negatywne lub obojętne - jest jedną z pierwszą z barier, którym osoby niepełnosprawne muszą stawić czoła (Majewski, 2005, s. 4070, a także podstawą przypisania im (z reguły niekorzystnych) ról społecznych (Kosakowski, 2003, s. 47).

Oczywiste w związku z tym wydaje się, że na istotę i wagę tych zagadnień zwrócono uwagę we wspomnianej Konwencji o Prawach Osób Niepełnosprawnych. O wysokiej randze i kluczowej roli przedmiotowej kwestii świadczy fakt, iż poświęcono jej w całości jedną z pierwszych części tego dokumentu. W art. 8, zatytułowanym „Podnoszenie świadomości” Państwa-Strony zobowiązują się podjąć natychmiastowe i efektywne działania, których celem ma być zwalczanie stereotypów, nieustanne podnoszenie świadomości społecznej i umacnianie poszanowania praw i godności osób z niepełnosprawnością. Artykuł ten zawiera również ramowy plan skutecznych działań dla nauczycieli w tym zakresie. W pkt 2, art. 8 Konwencji jest mowa o konieczności inicjowania działań rozwijających wrażliwość społeczeństwa, wzmacniających pozytywne postrzeganie osób z niepełnosprawnością. W podpunktach (b) i (d) mówi się kolejno o „rozwijaniu, na wszystkich szczeblach systemu edukacji, z uwzględnieniem wszystkich dzieci od najwcześniejszych lat, postawy poszanowania praw osób niepełnosprawnych” oraz ,popieraniu programów podnoszenia świadomości w sprawach dotyczących osób niepełnosprawnych i praw osób niepełnosprawnych" [http://www.unic.un.org.pl/dokumenty/Konwencja_Praw_Osob_Niepelnosprawnych.pdf]. 
Nie sposób odmówić słuszności wyżej wymienionym postulatom. Pojawia się jednak pytanie, jak optymalnie w warunkach codzienności akademickiej, wspomnianej niewystarczającej ilości czasu poświęconego wspomnianym zagadnieniom, sprostać zadaniu. Zwłaszcza że, jak zauważono, samo przekazanie wiedzy, nawet w atrakcyjny sposób, nie wystarcza. Przyszłym nauczycielom potrzebny jest również kontakt ze swoimi potencjalnymi uczniami - dopiero kombinacja obu tych elementów może zaowocować pozytywnym nastawieniem (por. Kirenko, 2002, s. 64). Jedynie w toku wzajemnych interakcji możliwe jest zweryfikowanie stereotypowych sądów, obiegowych opinii oraz przypisywanych przez środowisko schematycznych etykietek. W trakcie spotkań „twarzą w twarz” niwelują się: zakłopotanie, poczucie zawstydzenia czy obawy często towarzyszące samym już wyobrażeniom przypadkowego spotkania z osobą, która w jakikolwiek sposób jest ,inna”. Ponadto rozwija się postawa empatii, zrozumienia potrzeb drugiego człowieka. Dzięki relacjom, wspólnym działaniom druga osoba przestaje być „obca”, zaczyna należeć do grupy, którą określamy mianem „my”.

W dalszej części artykułu zostaną zaprezentowane przykłady dobrych praktyk, które w ciągu ostatnich trzech lat, podejmowane były w ramach zajęć ze studentami Uniwersytetu Marii Curie-Skłodowskiej w Lublinie. Ich uczestnikami były osoby studiujące pedagogikę oraz inne kierunki, w ramach których realizowany jest blok pedagogiczny. Zakres i formy współpracy wynika bezpośrednio z możliwości środowiska lokalnego. W Lublinie funkcjonuje wiele różnorodnych placówek, które bardzo chętnie włączają się w realizację idei społecznej integracji osób z niepełnosprawnością. Dzięki uprzejmości Dyrekcji oraz Pracowników, studenci UMCS uczestniczyli w spotkaniach, zajęciach i warsztatach w następujących placówkach:

- Specjalny Ośrodek Szkolno-Wychowawczy Nr 2 w Lublinie,

- Pracownia plastyczna działająca w Domu Pomocy Społecznej im. Matki Teresy z Kalkuty,

- Środowiskowy Dom Samopomocy-Ośrodek Wsparcia dla Osób z Zaburzeniami Psychicznymi w Matczynie,

- Fundacja Teatroterapia Lubelska,

Warsztaty Terapii Zajęciowej, ul. Wallenroda,

- Medyczne Studium Zawodowe im. prof. St. Liebharta,

- Spotkania Artystów Nieprzetartego Szlaku,

- Fundacja Szansa dla Niewidomych,

- Kapela Drewutnia,

- Stowarzyszenie na Rzecz Dzieci i Młodzieży z Niepełnosprawnością Ruchową, 
- Lubelskie Forum Organizacji Osób Niepełnosprawnych,

- Kościół pobrygidkowski.

Różne, w zależności od potrzeb, są cele organizowanych spotkań. Mogą one stanowić uzupełnienie/weryfikację teoretycznej, zdobytej na zajęciach, wiedzy. Tego typu spotkania organizowane były w Warsztatach Terapii Zajęciowej przy ul. Wallenroda oraz Stowarzyszeniu na Rzecz Dzieci i Młodzieży z Niepełnosprawnością Ruchową. Terapeuci oprowadzali studentów po swoich ośrodkach, wyjaśniali istotę prowadzonych działań o charakterze terapeutycznym, przedstawiali zasady rekrutacji i przyjęć osób do poszczególnych placówek. Studenci zdobyli wiedzę na temat specyfiki i form pracy z osobami $\mathrm{z}$ różnego rodzaju niepełnosprawnościami, rozwiać pojawiające się w tym zakresie wątpliwości, uzyskać odpowiedź na nurtujące ich pytania, dotyczące niekiedy bardzo kontrowersyjnych kwestii; poznali sprzęt używany podczas rehabilitacji. Efektem spotkań była przeprowadzona na zajęciach dyskusja dotycząca możliwości dostosowania środowiska szkoły masowej do potrzeb uczniów z określonym rodzajem niepełnosprawności. Podobny charakter mają wizyty w Medycznym Studium Zawodowym im. prof. St. Liebharta w Lublinie. Szkoła ta przygotowuje do pracy terapeutów zajęciowych. Studenci $\mathrm{w}$ trakcie spotkania dowiedzieli się nie tylko, na czym polega praca terapeuty zajęciowego, ale mogli też obserwować swoich kolegów i koleżanki podczas zajęć z teatroterapii oraz spróbować własnych sił podczas zajęć plastycznych wraz ze słuchaczami Studium przygotowywali stroiki i dekoracje świąteczne. Aby być na bieżąco z nowinkami technicznymi w zakresie udostępniania przestrzeni publicznej osobom z niepełnosprawnościa, studenci zwiedzali kościół pobrygidkowski, który po remoncie wyposażony jest w urządzenia ułatwiające zwiedzanie osobom z różnego rodzaju specjalnymi potrzebami. Na miejscu mogli sprawdzić i przeanalizować przydatność zastosowanych technologii. W tym celu wybrali się również do różnych obiektów użyteczności publicznej, aby z punktu widzenia osoby niepełnosprawnej ocenić ich dostępność. $\mathrm{W}$ ramach testowania nowych technologii jedna $\mathrm{z}$ grup uczestniczyła $\mathrm{w}$ specjalnym pokazie filmu z audiodeskrypcją. Na zajęciach gościliśmy przedstawiciela Fundacji Szansa dla Niewidomych, który przedstawił przygotowane dla osób z niepełnosprawnością wzrokową (w alfabecie brajla - dla niewidomych i druku powiększonym - dla słabo widzących) przewodniki po Lubelszczyźnie. Działania te mają na celu, oprócz dostarczenia wiedzy na temat udogodnień stosowanych w praktyce, zwrócenie uwagi studentów na obecność osób z niepełnosprawnością w życiu społecznym i ich możliwości w nim uczestnictwa, na fakt, iż życie tych osób nie ogranicza się tylko do leczenia 
czy rehabilitacji, ale toczy się w wielu przestrzeniach, tak jak życie każdego obywatela.

Spotkania i wizyty w placówkach traktuje się również jako sprawdzian gotowości studentów do wejścia w kontakt z uczniem ze specjalnymi potrzebami edukacyjnymi. Stają się też one płaszczyzną współpracy między studentami a wychowankami czy podopiecznymi goszczących placówek. Współpraca rozpatrywana z takiej perspektywy przynosi korzyści obu stronom: studentom oraz podopiecznym i wychowankom placówek i instytucji.

Na szczególną uwagę w tym względzie zasługują działania odbywające się w Specjalnym Ośrodku Szkolno-Wychowawczym nr 2 w Lublinie. Grupy studentów odwiedzające tę placówkę bywają w niej z reguły kilkukrotnie. Podczas pierwszego spotkania nauczyciele z Ośrodka przygotowują zajęcia w taki sposób, aby studenci mogli poznać specyfikę ich pracy, a jednocześnie włączyć się do tych zajęć, towarzysząc uczniom w wykonywaniu poszczególnych zadań, wchodząc tym samym w bezpośredni kontakt $\mathrm{z}$ uczniem ze specjalnymi potrzebami edukacyjnymi, poznając jego indywidualne potrzeby. Ponieważ zajęcia bardzo często mają charakter praktyczny (prace plastyczne, wykonywanie ozdób choinkowych, kart świątecznych), studenci dostrzegają możliwości dzieci niepełnosprawnych intelektualnie, mogą sprawdzić również swoje zdolności manualne. Gdy pierwsze lody w kontaktach zostają przełamane i studenci mają ochotę podjąć dalsze działania, włączają się w organizowanie lub sami organizują wydarzenia wpisane w kalendarz życia Ośrodka. Ze zrealizowanych działań można wspomnieć pomoc studentów przy organizacji jasełek oraz samodzielnie zorganizowany, w bardzo kreatywny sposób, Dzień Dziecka dla wychowanków zaprzyjaźnionej klasy drugiej. Podobne wydarzenie miało miejsce w Środowiskowym Domu Samopomocy-Ośrodku Wsparcia dla Osób z Zaburzeniami Psychicznymi w Matczynie. Studenci - bazując na zdobytej wcześniej wiedzy - przygotowali szereg aktywności dla uczestników imprezy i samodzielnie je przeprowadzili. Radość uczestników oraz satysfakcja z samodzielnie przygotowanego i zrealizowanego zadania stanowią koło napędowe do podejmowania dalszych działań.

Organizowane są również spotkania, podczas których następuje zamiana ról: studenci stają się odbiorcami, uczestnikami aktywności zaproponowanych przez osoby z niepełnosprawnością. Celem wspomnianych działań jest ukazanie studentom tych osób jako aktywnych, realizujących swoje pasje, a przede wszystkim posiadających konkretne umiejętności. Likwiduje się w ten sposób, zgodne z modelem medycznym niepełnosprawności, przekonanie, że osoba niepełnosprawna jest tylko nieproduktywnym biorca pomocy i wszelkiego 
wsparcia. Tego typu działania odbywają się w pracowni plastycznej działającej w Domu Pomocy Społecznej im. Matki Teresy z Kalkuty. Od wielu lat między innymi studenci mogą uczestniczyć w prowadzonych przez tworzących w pracowni artystów, warsztatach plastycznych. Osoby niepełnosprawne prezentują swoje osiagnięcia, wyjaśniają studentom tajniki swojej pracy, a następnie wspólnie tworzą prace plastyczne lub rękodzielnicze. Spotkania te są również okazją do bezpośredniej rozmowy o życiu, pasjach i marzeniach przy herbacie i ciastkach. Jak wynika z zebranych informacji zwrotnych, ten aspekt spotkań jest szczególnie wysoko oceniany zarówno przez studentów, jak i mieszkańców DPS-u. Podobne spotkanie odbyło się w Fundacji Teatroterapia Lubelska. Studenci najpierw zwiedzili placówkę, mieli okazję porozmawiać z uczestnikami warsztatów, a następnie wzięli udział w organizowanych, między innymi przez WTZ, dniach dzielnicy. Kolejnymi okazjami do poznania osób z niepełnosprawnością w roli artystów są wydarzenia cykliczne, takie jak Spotkania Artystów Nieprzetartego Szlaku - Przegląd Twórczości Osób Niepełnosprawnych - w zależności od pory roku studenci uczestniczą bądź to w Przeglądzie Piosenki, bądź w Spotkaniach teatralnych. Znakomitą okazją do spotkań są również działania jednorazowe, np.: wystawy prac, kiermasze, festyny itp.

Wszystkie wspomniane działania służą nie tylko zdobywaniu przez studentów kompetencji do pracy z uczniem o specjalnych potrzebach edukacyjnych, ale również stanowią przykład realizacji idei inkluzji. Pokazują studentom i utwierdzają ich w przekonaniu, że każda inność jest odmiana kondycji ludzkiej, a nie uzasadnieniem społecznego wykluczenia (M. R. Hebl).

\section{Wnioski}

Zgodnie z obowiązującymi przepisami na każdym poziomie edukacji możemy spotkać ucznia mającego specjalne potrzeby edukacyjne. Stąd w obszarze działań podejmowanych na rzecz tej grupy uczniów powinna znaleźć się wiedza teoretyczna, niezbędna do nabywania praktycznych umiejętności potrzebnych w pracy dydaktyczno-wychowawczej z różnymi grupami uczniów, w tym z niepełnosprawnym uczniem (Serafin, 2012, s. 34)

Kształcenie przyszłych nauczycieli, pedagogów na poziomie szkoły wyższej, a następnie ich dokształcanie, udział we wszelkiego typu działaniach służących realizacji idei inkluzji, powinno skupiać się przede wszystkim na dziecku, które uczy się i rozwija w indywidualnym tempie, a zadaniem dorosłych jest stworzyć mu warunki nauczania odpowiadające jego potrzebom, szczególnie gdy jest to dziecko ze specjalnymi potrzebami edukacyjnymi. Podstawą umie- 
jętności tworzenia sprzyjających warunków i indywidualizowania procesu nauczania ucznia ze specjalnymi potrzebami edukacyjnymi są: merytoryczna wiedza, której podstawy student zdobywa na studiach oraz pozytywne nastawienie do ucznia wyrosłe na wierze w jego możliwości oraz motywacji do odkrywania tkwiących w każdym dziecku potencjałów.

\section{Bibliografia}

Bereźnicki F. (2007), Dydaktyka kształcenia ogólnego, Impuls, Kraków.

Domagała-Zyśk E. (2012), Wstęp, [w:] E. Domagała-Zyśk (red.), Uczeń ze specjalnymi potrzebami edukacyjnymi w środowisku rówieśniczym, Wydawnictwo KUL, Lublin.

European Agency for Development In Special Needs Education - EADSNE (2009), Fundacja Rozwoju Systemu Edukacji.

Gajdzica Z. (2003), Wybrane uwarunkowania procesu kształcenia ucznia z lekkim upośledzeniem umystowym $w$ nizssych klasach szkoty podstawowej ogólnodostęnej, [w:] Z. Kazanowski, D. Osik-Chudowolska (red.), Integracja osób niepetnosprawnych w edukacji i integracjach społecznych, Wydawnictwo UMCS, Lublin.

Gałkowski T. (2008), Wzmacnianie zdrowia psychicznego w edukacji i wspomaganiu dzieci $z$ dysfunkcjami rozwojowymi, [w:] J. Kirenko (red.), Zdrowa szkoła - zdrowy uczeń, Wydawnictwo NeuroCentrum, Lublin.

Głodkowska J. (red.) (2010), Dydaktyka specjalna w przygotowaniu do ksztatcenia uczniów ze specjalnymi potrzebami edukacyjnymi. Podręcznik akademicki, Wydawnictwo APS, Warszawa.

Konwencja o Prawach Osób Niepetnosprawnych z dn. 25 października 2012 r. Dz. U. 1169, http://www.unic.un.org.pl/dokumenty/Konwencja_Praw_Osob_Niepelnosprawnych. $\operatorname{pdf}$ (dostęp:16.10.2013).

Kirenko J. (2002), Nie jesteś sam. Wsparcie społeczne osób z niepetnosprawnościq, Regionalny Ośrodek Polityki Społecznej i Zatrudnienia Urzędu Marszałkowskiego, Lublin.

Kirenko J., Gindrich P. (2007), Odkrywanie niepetnosprawności wzrokowej w nauczaniu właczajacym, Wydawnictwo Akademickie WSSP, Lublin.

Kosakowski Cz. (2003), Węzłowe problemy pedagogiki specjalnej, Wydawnictwo Edukacyjne Akapit, Torun.

Maciarz A. (2001), Przemiany w ujęciu istoty i uwarunkowań spolecznej integracji dzieci niepetnosprawnych, [w:] G. Dryżałowska (red.), Paradygmaty i przeobrażenia edukacji specjalnej w świetle dorobku profesora Aleksandra Hulka. Materiaty z ogólnopol- 
skiej konferencji naukowej Warszawa 24-25 maja 1999 r., Wydawnictwo Akademickie „Żak”, Warszawa.

Majewski T. (2005), Problemy rehabilitacji zawodowej i społecznej osób niepetnosprawnych, [w:] W. Dykcik (red.), Pedagogika specjalna, WN UAM, Poznań.

O’Regan F. J. (2005), Jak pracować z dziećmi o specjalnych potrzebach edukacyjnych, Wydawnictwo Liber, Warszawa.

Raport dobrych praktyk edukacyjnych: Szkoła się opłaca, http://www.efs.men.gov.pl/attachments/article/899/Ostateczna\%20wersja\%20Raportu.pdf-MEN (dostęp: 18.10. 2013).

Raport NIK - Kształcenie uczniów z niepełnosprawnościami o specjalnych potrzebach edukacyjnych, www.nik.gov.pl/plik/id,4585,vp,5892.pdf (dostęp:18.10. 2013).

Rozporzqdzenie MEN w sprawie zasad udzielania i organizacji pomocy psychologiczno-pedagogicznej z dn. 30 kwietnia 2013 r. Dz. U. 2013.532, http://www.lex.pl/du-akt/-/akt/ dz-u-2013-532 (dostęp:15.08.2013).

Rozporzqdzenie Ministra Edukacji Narodowej i Sportu z dn. 7 września 2004 w sprawie standardów kształcenia nauczycieli, Dz. U. z 2004 r., poz. 2110, http://www.infor.pl/dziennik-ustaw,rok,2004,nr,207/poz,2110,rozporzadzenie-ministra-edukacji-narodowej-isportu-w-sprawie-standardow.html (dostęp:15.10.2013).

Rozporzadzenie Ministra Nauki i Szkolnictwa Wyższego z dnia 17 stycznia 2012 r. w sprawie standardów kształcenia przygotowujacego do wykonywania zawodu nauczyciela, Dz. U. z 2012 r., poz. 131, http://isap.sejm.gov.p1/DetailsServlet?id=WDU20120000131 [dostęp:15.10.2013].

Serafin T. (2012), Kształcenie przyszłych nauczycieli w kontekście kwalifikacji formalnych i kompetencji merytorycznych, [w:] D. Podgórska-Jachnik (red.), Dobre praktyki pedagogiczne szansq innowacyjnej edukacji, PIKTOR, Łódź.

Skoczylas E. (2012), Dziecko z dysfunkcja wzroku w integracyjnym systemie kształcenia, [w:] E. Domagała- Zyśk (red.), Uczeń ze specjalnymi potrzebami edukacyjnymi w środowisku rówieśniczym, Wydawnictwo KUL, Lublin.

Sprawozdanie z realizacji Priorytetu III w ramach Programu Operacyjnego Kapitat Ludzki 2007-2013, http://www.efs.men.gov.pl/attachments/article/877/MEN_sprawozdanie PO_KL_III_za_I_procze_2010_r.pdf (dostęp:18.10. 2013).

www.brpd.gov.pl/wystapienia/wyst_2013_03_11.pdf - odpowiedź do raportu NIK (dostęp:18.10. 2013).

Wyczesany J., Gajdzica Z. (2006), Uwarunkowania edukacji i rehabilitacji uczniów o specjalnych potrzebach w rozwoju, Wydawictwo AP w Krakowie, Kraków. 
